\title{
Activation of Hedgehog Signaling in Aggressive Hepatic Hemangioma in Newborns and Infants
}

\author{
DANIELLE WENDLING-KEIM ${ }^{1}$, CHRISTIAN VOKUHL $^{2}$, CHRISTOPH WALZ $^{3}$, LYNN RIEDER $^{1}$, \\ RAINER GRANTZOW $^{1}$, DIETRICH VON SCHWEINITZ ${ }^{1}$, ROLAND KAPPLER ${ }^{1}$ and MICHAEL BERGER ${ }^{1}$ \\ ${ }^{1}$ Department of Pediatric Surgery, Dr. von Hauner Children's Hospital, \\ Ludwig-Maximilians-University Munich, Munich, Germany; \\ ${ }^{2}$ Kiel Pediatric Tumor Registry, Section of Pediatric Pathology, \\ Department of Pathology, Christian Albrechts University, Kiel, Germany; \\ ${ }^{3}$ Institute of Pathology, Faculty of Medicine, LMU Munich, Munich, Germany
}

\begin{abstract}
Background/Aim: Hepatic hemangiomas $(H H)$ can show an aggressive course with significant complications. Prognostic markers that identify an aggressive course are entirely absent. We recently showed that Hedgehog signaling is overexpressed in aggressive hemangiomas of the skin. Here, we hypothesize that it is also altered in aggressive $\mathrm{HH}$. Materials and Methods: Immunohistological staining for GLUT1 and quantitative PCR was performed in seven specimens with aggressive $H H$. For comparison, we included specimens of kaposiform hemangioendothelioma (KHE), skin hemangioma and normal liver tissue. Results: Overexpression of the Hedgehog signaling components SHH and GLI2 and its target gene FOXA2 in HH were similar to those found in aggressive skin hemangioma and KHE, their expression being significantly higher than in mild skin hemangioma. High expression levels of $\mathrm{SHH}$ and FOXA2 positively correlated with $\mathrm{HH}$, but not with normal liver tissue. Conclusion: Hedgehog signaling is up-regulated in aggressive HH. This finding may lead to a biomarker allowing early intervention.
\end{abstract}

Hepatic hemangiomas $(\mathrm{HH})$ are vascular tumors typically found in the pediatric liver. Their clinical behavior is usually harmless; however, at times they show an aggressive course with significant complications including bleeding, mass effect, and shunting of blood. Prognostic clinical or biological markers that can distinguish an aggressive from a

Correspondence to: Danielle Wendling, Department of Pediatric Surgery, Dr. von Hauner Children's Hospital, Ludwig-MaximiliansUniversity Munich, Lindwurmstr. 2a, D-80337 Munich, Germany. Tel.: +49 89440057810, Fax: +49 89440057815, e-mail: danielle.wendling@med.uni-muenchen.de

Key Words: Hepatic hemangioma, infants, hedgehog signaling, biomarkers. benign course are entirely absent $(1,2)$. With $16 \%$ of all hepatic tumors occurring during infancy, $\mathrm{HH}$ is the most common vascular tumor and the most common benign tumor of the liver in children (3).

The terminology of vascular lesions in the liver and especially angiomatous lesions in children is rather confusing. This uncertainty is largely due to the non-critical use of the terms hemangioma and hemangio-endothelioma, as well as the fact that the nomenclature has lately undergone several changes (4). The term hemangioendo-thelioma has previously been used to summarize a large variety of vascular neoplasms, including vascular malformations or lesions with a borderline biological behavior between benign infantile hemangiomas and highly malignant angiosarcomas $(5,6)$. Additionally, in the histopathology nomenclature, the terms hemangioma and hemangioendothelioma have been used synchronously to describe the same lesion. Further confusion arises from the nonchalant distinction between vascular lesions of the liver and the epithelioid hemangioendo-thelioma of the liver, a malignant tumor of childhood with metastatic potential.

According to the Boston Children's Hospital Vascular Anomalies Center, HHs now are divided into three categories: i) focal, ii) multifocal and iii) diffuse, depending on their clinical and radiological characteristics (1). Focal lesions stain GLUT1 negative on immunohistochemistry and are considered the equivalent of the rapidly involuting cutaneous hemangioma (RICH). Consequently, they are true congenital lesions (1). On the contrary, multifocal infantile hepatic hemangioma and diffuse infantile hepatic hemangioma stain positive for GLUT1 on immunohistochemistry $(1,7)$.

Since then, the term hemangioendothelioma is reserved for special tumor entities, for example the kaposiform hemangioendothelioma (KHE), an aggressive vascular tumor of the skin and soft tissues $(8,9)$. Although the term hemangioendothelioma is considered to be obsolete with respect to angiomatous lesions in the liver, some authors 
continue to use this term in an attempt to describe a subset of angiomatous vascular lesions of the liver that is believed to be associated with rapid growth as well as the potential for a more aggressive course, including the risk for KasabachMerritt syndrome (KMS) (9, 10). This nomenclature is unfortunate, because there is no corresponding international consensus for this usage nor are there any clinical, radiographic, histopathological or biological markers that would allow such a distinction. Moreover, it is today accepted that hepatic hemangiomas do not cause the full spectrum of the KMS (11).

Rather, these tumors show a transient thrombocytopenia and anemia, which, at times, has been mislabeled in the literature as KMS. Nevertheless, the transient thrombocytopenia seen in $\mathrm{HH}$ can be severe and may require urgent medical or surgical intervention (11). The only two entities that are known to have a definite association with the KMS are the tufted angioma and the KHE.

Most vascular lesions of the liver, including $\mathrm{HH}$, are detected in children during the first 6 months of life and a predominance of female patients has been reported (12-14). Most lesions are harmless, however, serious symptoms including abdominal mass, hepatomegaly, high-output cardiac failure, transient thrombocytopenia and coagulopathy as well as jaundice can occur $(15,16)$. Furthermore, malignant sarcomas, such as angiosarcoma have been reported to arise in existing $\mathrm{HH}(17,18)$.

Characteristically, like infantile hemangiomas of the skin, rapid proliferation during the first 6 months of life during phase 1 is followed by a plateau phase (phase 2) until about 12 months. Then, during phase 3 , the involuting phase begins and lasts up to 4-6 years (19-21). However, in HH, these stages can be intensified and prolonged, and symptomatic patients may need early treatment due to a high risk of severe complications (16). Although medical treatment modalities like propranolol (22-27), corticosteroids and interferon-alpha (INF- $\alpha$ ) are available, in some children it is necessary to resort to interventional therapy, such as surgical resection and liver transplantation $(9,28)$. A high risk of complications has been described for these surgical procedures when performed for vascular tumors of the liver (16).

Histologically, $\mathrm{HH}$ consist of immature and disorganized endothelial cells also containing endothelial progenitor cells (29). Traditionally, these lesions have been divided in type 1 and type 2 (30). Both types consist of a supporting fibrous stroma on which the endothelial cell layer sits. In type 1 lesions, cells consist of a single endothelial cell layer or very sporadically several layers. In type 2 lesions, endothelial cells are pleomorphic, larger and more hyperchromatic. Type 1 lesions typically show well-preserved bile ducts especially in the periphery of the lesion. In type 2 lesions, bile ducts are typically completely absent $(6,31,32)$. Sometimes, the differentiation of type 2 lesions from angiosarcoma can be challenging. This similarity has led to the widely spread but ultimately unproven impression that type 2 lesions are somehow associated with a more aggressive clinical behavior.

KHE is a vascular tumor infiltrating the skin, subcutis and muscle that can be complicated by the KMS. Although it is locally very extensive and aggressive, it does not metastasize. Similarly to focal $\mathrm{HH}$ and in contrast to diffuse and multifocal HH, KHE does not express GLUT1 (8, 3339). Characteristically, the lesion is composed of several solid nodules separated by connective tissue. These are composed of a mixture of small capillaries, solid lobules of endothelial cells and spindle cells $(38,40)$.

To date, the etiology and pathogenesis of $\mathrm{HH}$ is unknown (9). Further, no understanding exists as to what differentiates the large majority of cases that are harmless from the few that show aggressive growth with high morbidity. Although the hedgehog signaling pathway is implicated in embryonic development, vascularization and stem cell differentiation, its role on the pathogenesis of $\mathrm{HH}$ has not been investigated.

Core components of Hedgehog signaling are the ligand Sonic Hedgehog $(\mathrm{SHH})$, its receptor PATCHED $(\mathrm{PTCH})$, the transmembrane protein SMOOTHENED (SMO) and the transcription factors GLI as well as its target genes, such as FOXA2 $(41,42)$. In a previous study $(43)$, we have found an overexpression of the hedgehog signaling components $\mathrm{SHH}$, GLI2 and FOXA2 in infantile hemangiomas of the skin with especially aggressive progression requiring early resection. These findings are highly relevant because the hedgehog signaling pathway can potentially be targeted pharmaceutically. Therefore, it was the goal of this study to investigate whether hedgehog signaling components are overexpressed in aggressive $\mathrm{HH}$.

\section{Patients and Methods}

Patients. HH specimens from 7 patients aged 0 months to 4 years, who underwent corresponding liver resection at our institution from 2006-2016, were collected, snap-frozen and stored at $-80^{\circ} \mathrm{C}$. Informed consent was given by the parents of the patients. Similarly, for comparison specimens from 3 children with KHE were collected. A retrospective chart review was carried out, including the analysis of pathology reports. All specimens were re-evaluated by a pathologist with specific expertise in pediatric tumors and hemangioma. Patient records were analyzed, and all data were irreversibly anonymized. Our Institutional Review Board and our Ethics committee approved the study. For further comparison with our results, previously obtained and published data on the expression levels of genes in aggressive infantile hemangioma of the skin were used (43).

Real-time reverse transcription-PCR (RT-PCR). Total RNA was extracted from fresh frozen hepatic hemangioma tissues. RNA was depleted from DNA and was subsequently purified using the RNAse free DNAse set and RNeasy Mini Kit from Qiagen (Hilden, Germany), according to the manufacturer's protocol. The concentration of RNA 
Table I. Patient clinical features.

\begin{tabular}{|c|c|c|c|c|c|c|c|c|}
\hline No. & Gender & $\begin{array}{c}\text { Age at } \\
\text { diagnosis }\end{array}$ & Symptoms & Localization & $\begin{array}{l}\text { Imaging } \\
\text { findings }\end{array}$ & $\begin{array}{l}\text { Lesion } \\
\text { size }\end{array}$ & $\begin{array}{l}\text { Medical } \\
\text { treatment }\end{array}$ & $\begin{array}{c}\text { Kasabach } \\
\text { Merritt }\end{array}$ \\
\hline 1 & $\mathrm{~F}$ & Prenatally & None & Liver, unifocal & $\begin{array}{l}\text { Single large } \\
\text { solid mass }\end{array}$ & $7 \times 8 \mathrm{~cm}$ & $\begin{array}{c}\text { Cortisone, } \\
\text { no effect }\end{array}$ & $\mathrm{N}$ \\
\hline 2 & M & 4 months & None & Liver, unifocal & $\begin{array}{l}\text { Single mass with } \\
\text { calcifications }\end{array}$ & $7.9 \times 5.2 \times 7.2 \mathrm{~cm}$ & None & $\mathrm{N}$ \\
\hline 3 & M & 5 months & $\begin{array}{l}\text { Recurrent } \\
\text { vomiting }\end{array}$ & Liver, unifocal & $\begin{array}{l}\text { Single homogenous } \\
\text { mass }\end{array}$ & N/A & None & $\mathrm{N}$ \\
\hline 4 & M & 2 weeks & $\begin{array}{l}\text { Cardiac and respiratory } \\
\text { insufficiency postnatally, } \\
\text { rapid growth despite } \\
\text { of treatment with } \\
\text { propranolol }\end{array}$ & Liver, unifocal & Single mass & $7.5 \times 3.1 \mathrm{~cm}$ & $\begin{array}{l}\text { Propranolol, } \\
\text { no effect }\end{array}$ & $\mathrm{N}$ \\
\hline 5 & $\mathrm{~F}$ & Postnatally & $\begin{array}{l}\text { Liver mass, rapid } \\
\text { growth at age } 4 \text { years }\end{array}$ & $\begin{array}{l}\text { Liver, } \\
\text { multifocal }\end{array}$ & $\begin{array}{l}\text { Single inhomogenous } \\
\text { mass }\end{array}$ & $12.4 \times 6.2 \times 11.3 \mathrm{~cm}$ & None & $\mathrm{N}$ \\
\hline 6 & M & 4 months & $\begin{array}{l}\text { Vomiting due to } \\
\text { compression of } \\
\text { the stomach }\end{array}$ & Liver, unifocal & $\begin{array}{l}\text { Solid mass } \\
\text { compressing } \\
\text { the stomach }\end{array}$ & $3.2 \times 3.2 \mathrm{~cm}$ & None & $\mathrm{N}$ \\
\hline 7 & $\mathrm{~F}$ & Postnatally & Cardiac insufficiency & Liver, unifocal & $\begin{array}{c}\text { Single inhomogenous } \\
\text { mass }\end{array}$ & $3.5 \times 2.5 \times 1.7 \mathrm{~cm}$ & None & $\mathrm{N}$ \\
\hline 8 & $\mathrm{~F}$ & 16 months & $\begin{array}{c}\text { Rapid growth, } \\
\text { Hemolysis, acute } \\
\text { liver failure, sepsis; } \\
\text { death at age } 23 \text { months }\end{array}$ & Face and Neck & $\begin{array}{l}\text { Inhomogenous } \\
\text { mass }\end{array}$ & N/A & $\begin{array}{l}\text { Chemotherapy } \\
\text { Vincristin, } \\
\text { Actinomycin D, } \\
\text { Cyclophsphamid }\end{array}$ & $\mathrm{Y}$ \\
\hline 9 & M & Postnatally & $\begin{array}{l}\text { Reduced movement } \\
\text { of right leg postnatally, } \\
\text { hip luxation }\end{array}$ & Thigh and Leg & $\begin{array}{l}\text { Inhomogenous } \\
\text { mass }\end{array}$ & N/A & $\begin{array}{l}\text { Chemotherapy } \\
\text { Vincristin, Actinomycin } \\
\text { D, Cyclophsphamid }\end{array}$ & in \\
\hline 10 & $\mathrm{~F}$ & Postnatally & $\begin{array}{l}\text { Visible tumor } \\
\text { postnatally }\end{array}$ & Thigh and Groin & $\begin{array}{l}\text { Inhomogenous } \\
\text { mass }\end{array}$ & N/A & $\begin{array}{c}\text { Propranolol + } \\
\text { Tranexam, Vincristin, } \\
\text { Prednisolone, Laser }\end{array}$ & Y \\
\hline
\end{tabular}

was measured by photometry (BioPhotometer, Eppendorf, Hamburg, Germany) and the RNA was stored at $-80^{\circ} \mathrm{C}$.

Reverse transcription of total RNA was carried out using random hexamers (Roche Diagnostics, Penzberg, Germany) and SuperScriptII reverse transcriptase (Invitrogen, Carlsbad, CA, USA). PCR amplifications were carried out with $40 \mathrm{ng}$ of cDNA, $500 \mathrm{nM}$ forward and reverse primers and iTaq SYBR Green Supermix (Bio-Rad Laboratories, Hercules, CA, USA) on a Mastercycler Realplex2 cycler (Eppendorf, Hamburg, Germany) with 40 cycles consisting of a 15 second (s) denaturation at $95^{\circ} \mathrm{C}$, primer annealing for $15 \mathrm{~s}$ at 55 $58^{\circ} \mathrm{C}$ depending on the primer, and extension for $30 \mathrm{~s}$ at $72^{\circ} \mathrm{C}$. All experiments were performed in doublets. Amplification of the housekeeping gene TATA-Box-binding-Protein (TBP) was performed to standardize the amount of sample RNA. Relative quantification of gene expression was performed using the $\Delta \Delta \mathrm{ct}$ method, which is a standard procedure (44). Forward $(\mathrm{F})$ and reverse $(\mathrm{R})$ primers were as follows ('5->'3 orientation):

$F G F 2$, F': GACCTCACATAAGCTACAACTTC, R': AGACACA ACTCCTCTCTCTTCTGCT GLUT1, F': TCCACGTCCAGCT GCCAT, R': AGGGACCACACAGTTGCTCC

GLI, F'2: TTTGAAGCACCTACACTGGCA, R': TCTCTTCTTG TTCCTTGGACACTG

FOXA2, F': AGAAGCGCCAGAAGTGTCGT, R': GCCCCATC CTCAGACTCTGAC
$S H H, F^{\prime}:$ AAGGACTTCGTGTCAGCCCTTC, R': CGGGCTAGG CACACAAGCT

TBP, F': GCCCGAAACGCCGAATAT, R': CCGTGGTTCGTG GCTCTCT

Immunohistochemistry. Immunohistochemical analysis of GLUT1 expression was performed on $2 \mu \mathrm{m}$ sections mounted on glass slides in a Leica Bond-Max automated immunostainer (Leica Microsystems Inc., Bannockburn, Ireland). Heat-induced epitope retrieval was performed with a BOND epitope retrieval solution, $\mathrm{pH} 9$ (Leica Biosystems, Nussloch, Germany) for 20 minutes. The GLUT1 polyclonal antibody (Zytomed, Berlin, Germany) was diluted 1:50 and the sections were incubated for 30 minutes, followed by the addition of the BOND Polymer Detection Kit (Leica Biosystems) (15 minutes). 3,3'Diaminobenzidine Tetrahydrochloride (Leica Biosystems) was used as a chromogen with a subsequent haematoxylin counterstain.

Statistical analysis. Data were expressed as a mean \pm standard deviation and were subjected to Student's unpaired $t$-test and Spearman's rank correlation. A level of $p<0.05$ was considered significant.

\section{Results}

Patients' demographics and histology. All seven patients with $\mathrm{HH}$ were children between the ages 0 weeks and 12 months at 

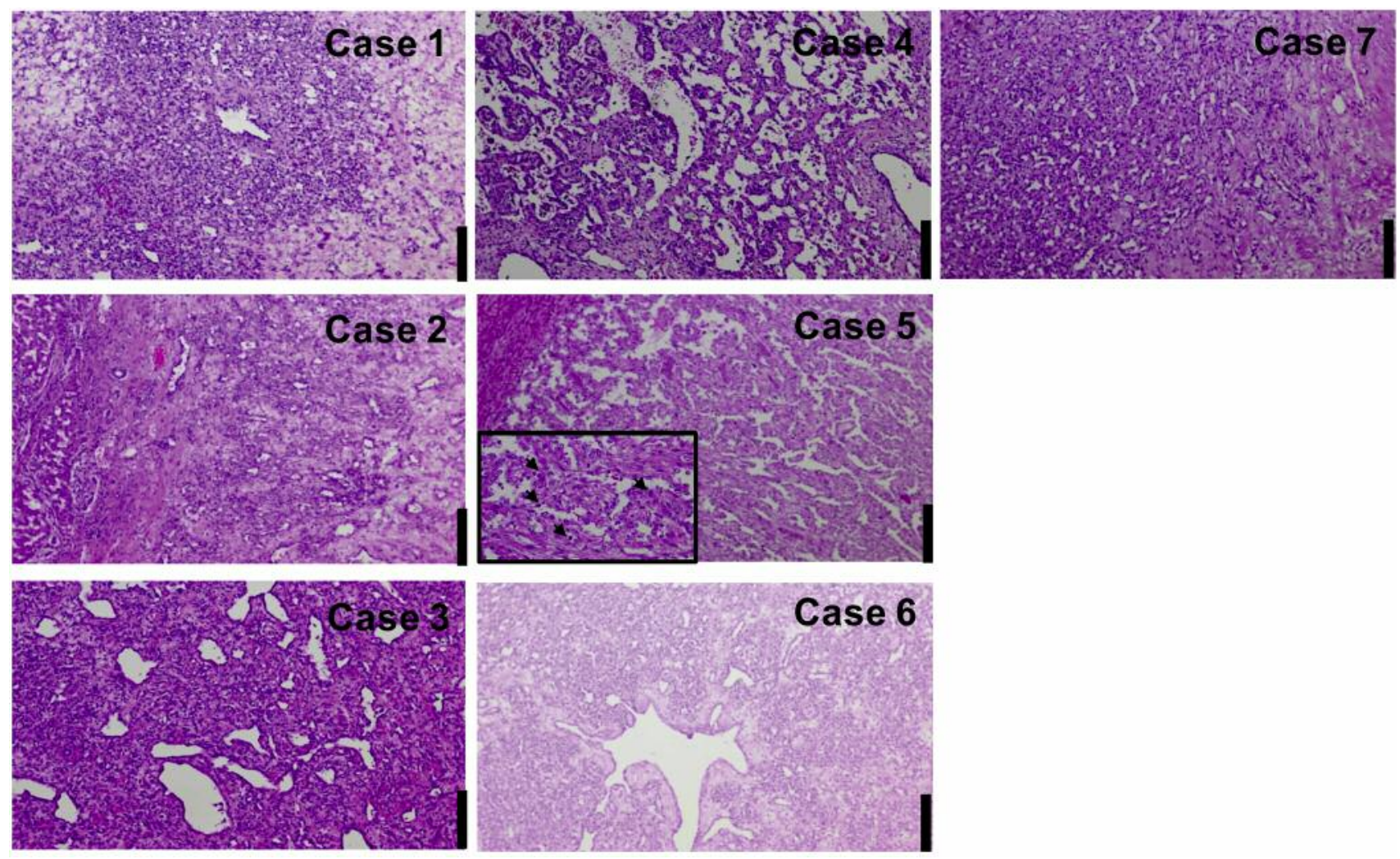

Figure 1. Histology of hepatic hemangioma. Cases 1-4 and 6: HH with typical histologic appearance and focal regressive changes. Case 5: Hemangioma of the liver with transformation in angiosarcoma. High-power magnification (inlay) displays severe atypia which is marked by arrows. Case 7: HH with regressive changes Scale bars: $200 \mu \mathrm{m}$.

the time of diagnosis (Table I). Three children were girls. Six children had unifocal lesions and one had a multifocal lesion confined to segments 2 and 3 as well as additional subcutaneous hemangiomatosis. Although one child showed transient anemia and thrombocytopenia, none of the children met the definition of KMS. All seven children with $\mathrm{HH}$ underwent resection for a variety of reasons (Table II). Due to the location of the $\mathrm{HH}$, two children underwent formal rightsided hepatectomy, three underwent resection of the left lateral segment (segments 2 and 3), and one underwent nonanatomical liver resection for a tumor of the left lobe. At the time of operation, children were between 2 weeks and 4 years old. Six children were operated on before the age of 16 months, and one child who was operated at the age of 4 years was a child with the multifocal tumor and the subcutaneous hemangiomatosis whose tumor, after a stable growth phase and despite having no symptoms, showed new progressive growth at the age of 4 years. There were no relevant postoperative complications in any of the cases. The histology of all specimens of patients with HH is shown in Figure 1. Notably, in case 5 (Figure 1), a multifocal hepatic hemangioma with a focally aggressive area (DD: transformation in angiosarcoma) was diagnosed. The six unifocal cases stained negative for GLUT1 on immunohistochemistry, while the one multifocal case stained positive.

Three children with KHE were included in the study for comparison. All children had KMS. Two underwent biopsy to confirm diagnosis, and one underwent partial resection due to the large mass of the tumor. Six specimens with normal liver tissue were used for comparison.

HH express both FGF2 and GLUT1 on mRNA level. Initially, we tested the degree of expression of two known marker genes of angiomatous lesions. Levels of the fibroblast growth factor 2 (FGF2), which is a known marker of infantile hemangioma (45), and glucose transporter 1 (GLUT1), which is expressed in multifocal and diffuse $\mathrm{HH}$, but not in unifocal $\mathrm{HH}$ and $\operatorname{KHE}(7,35,46,47)$ were analyzed. Analysis of FGF2 expression showed similar expression levels in all specimens tested, that is, in infantile hemangiomas of the skin (both mild and severe), $\mathrm{HH}$ (all combined), KHE and normal liver tissue (Figure 2A). Even though six of the seven children with $\mathrm{HH}$ analyzed had unifocal lesions that did not stain positive for GLUT1 using 
A
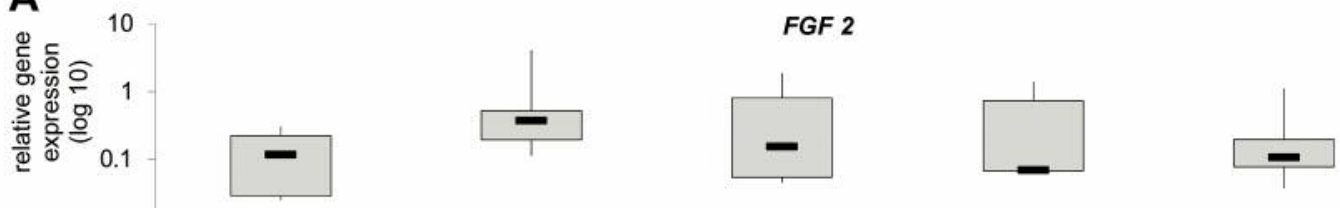

0.01

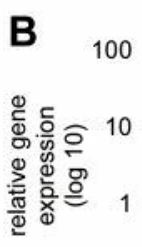

0.1

Mild hemangioma of the Severe hemangioma of Hepatic Hemangioma skin
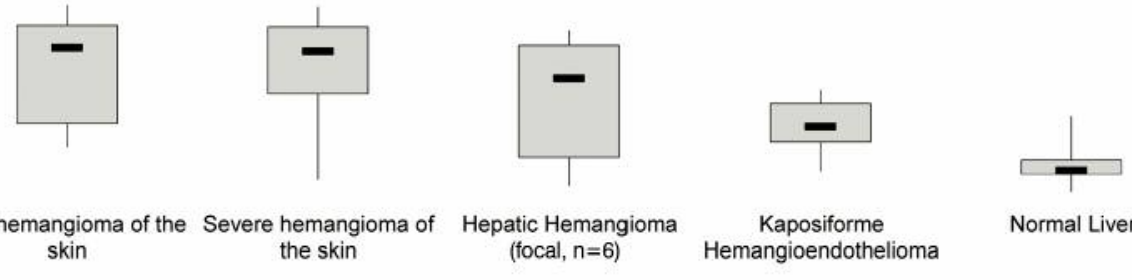

Normal Liver

Hepatic Hemangioma Single Data point (multifocal, $n=1$ )

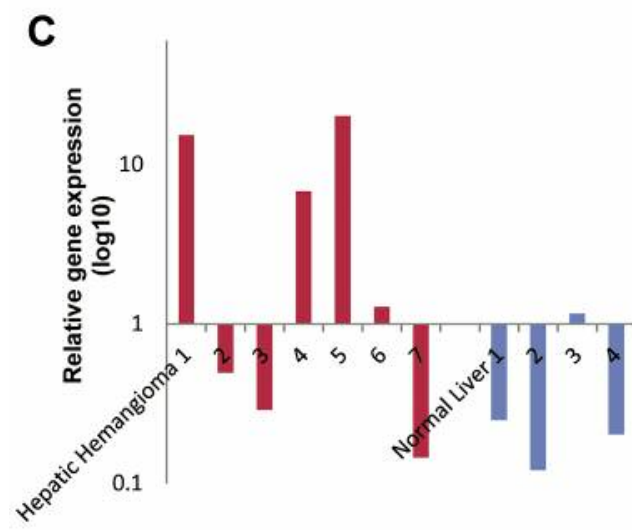

Relative expression of GLUT1

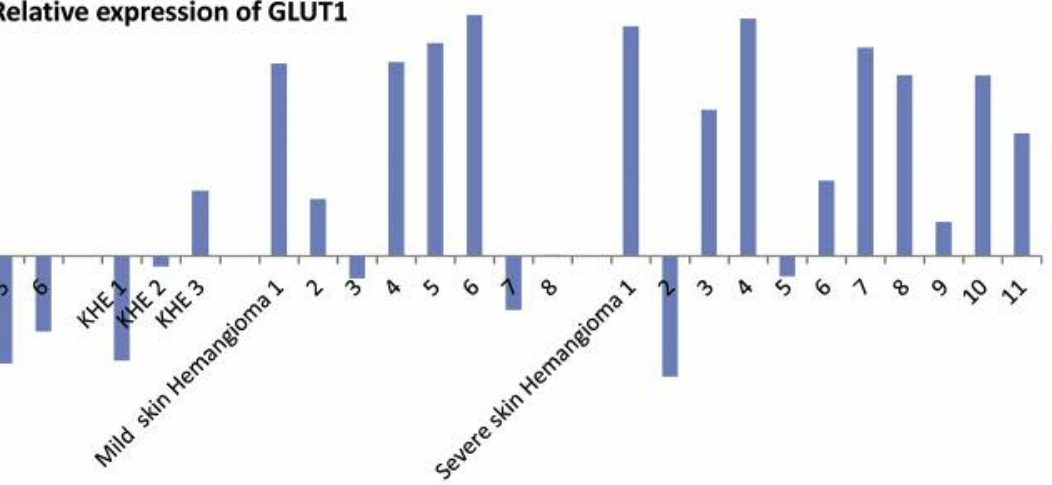

Figure 2. FGF2 and GLUT1 are poor markers for aggressive HH. Expression analysis revealed comparable levels of FGF2 in all tumors and tissues studied (A). Remarkably, GLUT1 expression varied in different tumors (B, case numbers of the hepatic hemangiomas are given on the x-axis), but was extremely low in normal liver tissue $(C)$.

Table II. Histopathological findings and details regarding the performed surgery.

\begin{tabular}{|c|c|c|c|c|c|c|}
\hline No. & Gender & $\begin{array}{l}\text { Age at } \\
\text { operation }\end{array}$ & $\begin{array}{l}\text { Indication for } \\
\text { surgery }\end{array}$ & Operation & GLUT1 & $\begin{array}{l}\text { Pathological } \\
\text { features }\end{array}$ \\
\hline 1 & $\mathrm{~F}$ & 16 months & Large Tumor mass & $\begin{array}{c}\text { Laparoscopic biopsy, } \\
\text { Right sided Hemihepatectomy }\end{array}$ & Negative & $\begin{array}{l}\mathrm{HH} \text {, infantile Dehner } 1, \\
\text { focally type } 2\end{array}$ \\
\hline 2 & M & 4 months & Large Tumor mass & Wedge resection & Negative & $\mathrm{HH}$, infantile Dehner 1 \\
\hline 3 & M & 6 months & Recurrent vomiting & Right sided Hemihepatectomy & Negative & HH, infantile Dehner 1 \\
\hline 4 & M & 1 month & $\begin{array}{l}\text { Cardiac and Respiratory } \\
\text { insufficiency postnatally, rapid } \\
\text { growth despite of treatment }\end{array}$ & & & \\
\hline & & & with propranolol & Resection Segment 2 und 3 & Negative & HH, infantile Dehner 1 \\
\hline 5 & $\mathrm{~F}$ & 4 years & Rapid growth at age 4 years & Resection Segment 2 und 3 & Positive & $\begin{array}{l}\text { Multinodular HH with } \\
\text { focal angiosarcoma }\end{array}$ \\
\hline 6 & M & 5 months & Vomiting due to compression & Resection Segment 2 und 3 & Negative & $\mathrm{HH}$ \\
\hline 7 & $\mathrm{~F}$ & 12 days & Cardiac insufficiency & Resection Segment 2 und 3 & Negative & $\mathrm{HH}$ \\
\hline 8 & $\mathrm{~F}$ & 16 months & Tumor growth & Biopsy & Negative & KHE \\
\hline 9 & M & 4 months & Diagnostic measure & Biopsy & Negative & KHE \\
\hline 10 & $\mathrm{~F}$ & 8 months & Tumor growth & Partial Resection & Negative & KHE \\
\hline
\end{tabular}




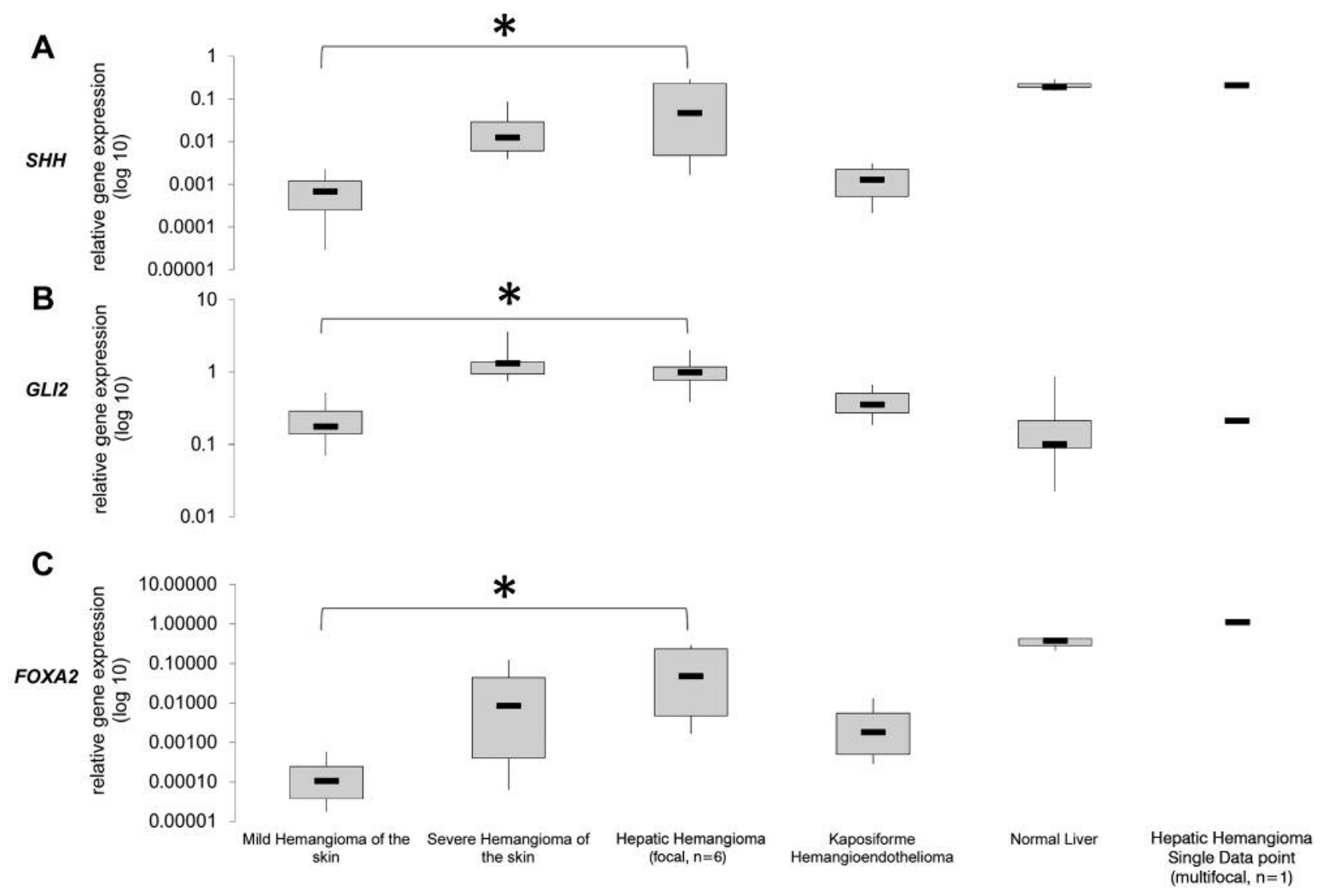

Figure 3. Hedgehog components SHH, GLI2 and FOXA2 are significantly overexpressed in HH. Expression levels of SHH (A), GLI2 (B) and FOXA2 (C) are shown for $\mathrm{HH}$ and control tissues. ${ }^{*} p<0.05$.

immunohistochemistry, we opted to analyze this marker nevertheless, since protein does not necessarily correlate with mRNA expression due to post-transcriptional regulation or other factors. Interestingly, in our analysis, two of the six unifocal cases of HH did express GLUT1 at the mRNA level, as did the case with the multifocal tumor, although to different degrees. Analysis of GLUT1 expression further demonstrated, that its levels in $\mathrm{HH}$ were comparable to the expression of hemangiomas of the skin, but it was higher compared to the expression in normal liver tissue (Figure 2B). The relative gene expression of the only specimen that showed a GLUT1-positive immunohistology stain is shown separately.

Hedgehog signaling is over-activated in Hepatic Hemangioma. In order to identify genes that may be involved in the proliferation of $\mathrm{HH}$, we re-evaluated the gene expression profiling that we previously published for cutaneous infantile hemangioma. The study had shown that hedgehog signaling is increased in infantile hemangioma of the skin with an aggressive course (43). More specifically, expression levels of SHH, FOXA2 and GLI2 were upregulated in aggressive hemangiomas compared to hemangiomas with a milder course.

Therefore, we next analyzed whether hedgehog signaling is altered in $\mathrm{HH}$ by investigating the expression levels of the above-mentioned genes in $\mathrm{HH}$ specimens using quantitative RT-PCR.

As shown in Figure 3, the expression levels of GLI2, SHH and FOXA2 in $\mathrm{HH}$ are similar to those found in aggressive hemangioma of the skin ( $p=0.5490$ for GLI2, $p=0.6451$ for SHH and $p=0.8583$ for FOXA2) and KHE, which in turn are significantly higher than those of mild hemangioma of the skin ( $p=0.0010$ for $G L I 2, p=0.0311$ for $S H H$ und $p=0.0388$ for FOXA2). We found high expression levels of hedgehog signaling components in normal liver tissue (Figure 3). Furthermore, we correlated SHH to its target genes FOXA2 and GLI2 using the Spearman's rank correlation coefficient (Figure 4). Here, we found a strong correlation of $\mathrm{SHH}$ with FOXA2 for HH (Figure 4A) (r=0.82143, $p=0.02345)$, but none for normal liver tissue (Figure 4B) $(\mathrm{r}=-0.14286$, $p=0.78717)$. In contrast, there was no correlation between 
A

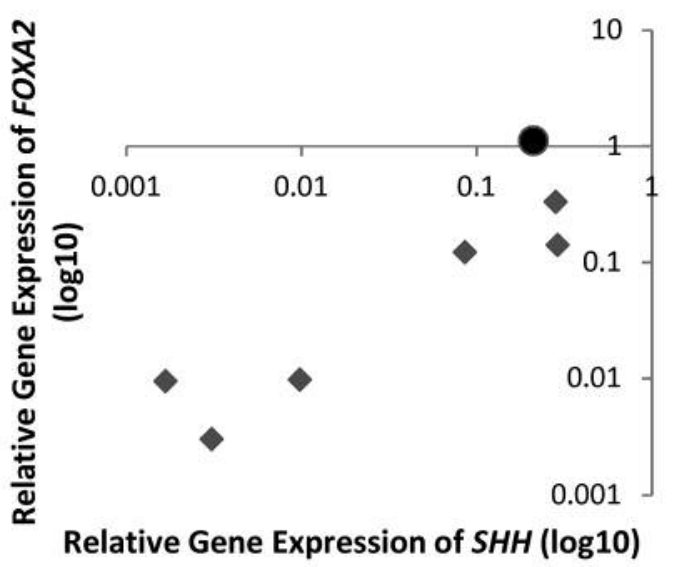

Correlation of $\mathrm{SHH}$ and

FOXA2 in Hepatic

Hemangioma

Rho $=0.82143$

$p=0.02345$
B

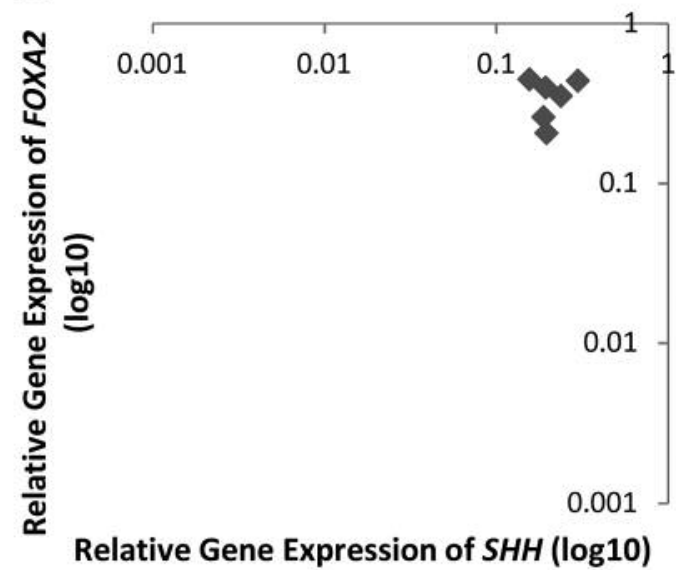

No Correlation of $\mathrm{SHH}$

and FOXA2 in Normal

Liver Tissue

Rho $=0.1667$

$p=0.703$

Figure 4. SHH correlates with its target gene FOXA2 in HH. (A) Correlation analysis off SHH and its target gene FOXA2 of each individual patient with HH using the Spearman's rank correlation coefficient. The data point of the GLUT1 positive HH is marked by a circle. (B) The same analysis for normal liver tissue.

$S H H$ and GLI2 (r=0.3095, $p=0.4618)$ or between GLI2 and FOXA2 ( $\mathrm{r}=0.1667, p=0.7033)$ in $\mathrm{HH}$ (data not shown). These findings suggest that genes involved in hedgehog signaling may be involved with progression in $\mathrm{HH}$.

\section{Discussion}

$\mathrm{HH}$ in children are frequent and usually harmless. Nevertheless, isolated cases show enhanced growth and can lead to significant morbidity $(48,49)$. The understanding why some $\mathrm{HH}$ show a more aggressive behavior than most $\mathrm{HH}$ is scarce. Here, for the first time, we analyzed the hedgehog signaling pathway in aggressive $\mathrm{HH}$ and found significant activation similar to the one in aggressive hemangioma of the skin. Therefore, our results hint that hedgehog signaling may potentially have a critical role in the tumor development and progression of $\mathrm{HH}$ in children. In such a case, our findings could have significant clinical impact because hedgehog signaling can then serve not only as a potential prognostic marker but also, more importantly, as a potential drug target for hedgehog antagonists.

Several other alterations have been investigated in $\mathrm{HH}$ in an attempt to unravel its pathogenesis and potentially find predictors of aggressive tumor behavior. Alterations of VEGF and NOTCH-signaling amongst others have been found in
$\mathrm{HH}$ and studies have pointed to a placental origin of endothelial cells in these lesions (50). Moreover, FGF2 has been described as a marker for hemangioma and has been discussed controversially regarding its level of expression during proliferation as compared to involution $(21,51,52)$. GLUT1 is another frequently used marker of $\mathrm{HH}(53,54)$, however, etiology and pathogenesis of the $\mathrm{HH}$ are not fully understood. Most notably, to date no markers have been found to detect $\mathrm{HH}$ with especially severe progression.

In this study, we examined freshly-frozen tissue of $\mathrm{HH}$ and compared our findings with specimens from KHE and normal liver, as well as previously published data from cutaneous hemangioma. In a first set of experiments, we determined whether the expression level of the known hemangioma marker $F G F 2$ was alternated and could potentially be a marker of aggressive $\mathrm{HH}$. We found that the expression level of FGF2 in $\mathrm{HH}$ was similar to that of $\mathrm{KHE}$ and of normal liver tissue. This is in accordance with what we have previously described for the expression of FGF2 in cutaneous hemangioma, where $F G F 2$ did not serve as a marker to differentiate between aggressively and mildly proliferating cutaneous hemangiomas (55).

Next, we investigated the expression level of GLUT1, a frequently used marker of infantile, but not of congenital hemangioma $(53,54)$. However, since focal lesions of $\mathrm{HH}$ 
do not stain positive for GLUT1 on immunohistochemistry, it was unlikely that GLUT1 would be an appropriate prognostic tool for aggressive growth in $\mathrm{HH}$. We found that two of the five lesions, despite being focal and staining negative for GLUT1 on immunohistochemistry, did express GLUT1. It is unclear how this finding may be interpreted at this time. One potential explanation could be a lack of translation of the expressed of mRNA for GLUT1 in these lesions. However, why only two of the lesions would express GLUT1, and not all, is currently not apparent to us. Nevertheless, our results indicate that neither $F G F 2$ nor GLUT1 can serve as potential markers for detecting aggressive behavior in $\mathrm{HH}$.

Our previous study on Hedgehog signaling in cutaneous hemangiomas (43) had led us to the analysis of Hedgehog signaling in aggressive $\mathrm{HH}$. We detected an overexpression of $S H H$ as well as of GLI2 and FOXA2 in all HH compared to mild cutaneous hemangiomas and to KME.

FOXA2, as a target gene of Hedgehog signaling, is transcriptionally activated through $G L I$-binding-sites (5658). Notably, expression levels of FOXA2 and $S H H$ showed a positive correlation, which substantiates a potential role of Hedgehog signaling in $\mathrm{HH}$. Importantly, normal liver tissue showed high levels of hedgehog components overall, but when we compared each value to the individual patient we found no correlation between $\mathrm{SHH}$ and its target gene FOXA2, and we, thus, identified a true activation of hedgehog signaling only in $\mathrm{HH}$, but not in normal liver tissue. These findings are in accordance with previous studies that show an autocrine activation of the hedgehog pathway in a large variety of tumors, including tumors of the colon and the pancreas $(7,42,59)$. In our study, we found similarly elevated hedgehog signaling and ligand overexpression in the same individual patient, hinting an autocrine activation mechanism in $\mathrm{HH}$.

Our study has at least three limitations. First, the retrospective nature of our study generates a selection bias of the cases evaluated. However, it was our intent to analyze specifically lesions that displayed an aggressive behavior, which in our case were defined as those that required resection. Second, our case number is low. Although $\mathrm{HH}$ are frequently seen in our patient population, the number of children that ultimately require aggressive surgical treatment or even only a biopsy is miniscule. Given our current results, the future goal is to enhance national and international collaboration with other high-volume centers in order to conduct larger studies. Third, our study lacks a true control. A true control would have been tissue from a set of patients with non-aggressive $\mathrm{HH}$ who showed no indication for resection. Obviously, acquisition of such tissue is not possible for ethical reasons. We tried to compensate for this shortcoming by including the analysis of tissue of other hemangiomas, including cutaneous hemangiomas with mild clinical behavior, as well as tissue from both KHE and normal liver tissue.

In conclusion, in this study, for the first time, we describe a significant overexpression of the hedgehog signaling components $\mathrm{SHH}$ and $\mathrm{GLI}$, as well as its target gene FOXA2 in aggressive $\mathrm{HH}$, and propose these genes as potential prognostic biomarkers for aggressive growth enabling early treatment. Importantly, Hedgehog signaling could serve as a potential drug target in these lesions. More research is needed to clarify the exact role of hedgehog signaling and its importance in tumor progression in $\mathrm{HH}$.

\section{Conflicts of Interest}

The Authors have no conflicts of interest to declare.

\section{Authors' Contributions}

DWK, RK and MB designed the study, performed the research, analyzed the data and wrote the paper. $\mathrm{CV}$ and $\mathrm{CW}$ performed the research. LR, RG and DvS provided clinical data, collected patients' photographs and analyzed data.

\section{Acknowledgements}

We are grateful to Fatemeh Promoli for technical assistance.

\section{References}

1 Christison-Lagay ER, Burrows PE, Alomari A, Dubois J, Kozakewich HP, Lane TS, Paltiel HJ, Klement G, Mulliken JB and Fishman SJ: Hepatic hemangiomas: Subtype classification and development of a clinical practice algorithm and registry. $\mathbf{J}$ Pediatr Surg 42(1): 62-67; discussion 67-68, 2007. PMID: 17208542. DOI: 10.1016/j.jpedsurg.2006.09.041

2 Rialon KL, Murillo R, Fevurly RD, Kulungowski AM, Christison-Lagay ER, Zurakowski D, Kozakewich HP, Alomari AI and Fishman SJ: Risk factors for mortality in patients with multifocal and diffuse hepatic hemangiomas. J Pediatr Surg 50(5): 837-841, 2015. PMID: 25783331. DOI: 10.1016/ j.jpedsurg.2014.09.056

3 Erdogan D, Busch OR, van Delden OM, Bennink RJ, ten Kate FJ, Gouma DJ and van Gulik TM: Management of liver hemangiomas according to size and symptoms. J Gastroenterol Hepatol 22(11): 1953-1958, 2007. DOI: 10.1111/j.14401746.2006.04794.x

4 Iacobas I, Phung TL, Adams DM, Trenor CC, 3rd, Blei F, Fishman DS, Hammill A, Masand PM and Fishman SJ: Guidance document for hepatic hemangioma (infantile and congenital) evaluation and monitoring. J Pediatr 203: 294-300 e292, 2018. PMID. DOI: 10.1016/j.jpeds.2018.08.012

5 Requena L and Kutzner H: Hemangioendothelioma. Semin Diagn Pathol 30(1): 29-44, 2013. PMID: 23327728. DOI: 10.1053/j.semdp.2012.01.003

6 Dehner LP and Ishak KG: Vascular tumors of the liver in infants and children. A study of 30 cases and review of the literature. Arch Pathol 92(2): 101-111, 1971. PMID: 5559952. 
7 Mo JQ, Dimashkieh HH and Bove KE: Glut1 endothelial reactivity distinguishes hepatic infantile hemangioma from congenital hepatic vascular malformation with associated capillary proliferation. Hum Pathol 35(2): 200-209, 2004. PMID: 14991538

8 Wassef M, Blei F, Adams D, Alomari A, Baselga E, Berenstein A, Burrows P, Frieden IJ, Garzon MC, Lopez-Gutierrez JC, Lord DJ, Mitchel S, Powell J, Prendiville J, Vikkula M, Board I and Scientific C: Vascular anomalies classification: Recommendations from the international society for the study of vascular anomalies. Pediatrics 136(1): e203-214, 2015. PMID: 26055853. DOI: 10.1542/peds.2014-3673

9 PDQ Pediatric Treatment Editorial Board: Pdq childhood vascular tumors treatment. Bethesda, MD, USA: National cancer institute. Updated: 08/11/2016. Available at: https://www.cancer.gov/ types/soft-tissue-sarcoma/patient/child-vascular-tumors-treatmentpdq. Last accessed: 11/11/2016. PMID: 26844334.

10 Frieden IJ, Haggstrom AN, Drolet BA, Mancini AJ, Friedlander SF, Boon L, Chamlin SL, Baselga E, Garzon MC, Nopper AJ, Siegel DH, Mathes EW, Goddard DS, Bischoff J, North PE and Esterly NB: Infantile hemangiomas: Current knowledge, future directions. Proceedings of a research workshop on infantile hemangiomas, april 7-9, 2005, bethesda, maryland, USA. Pediatr Dermatol 22(5): 383-406, 2005. DOI: 10.1111/j.1525-1470.2005. 00102.x

11 Baselga E, Cordisco MR, Garzon M, Lee MT, Alomar A and Blei F: Rapidly involuting congenital haemangioma associated with transient thrombocytopenia and coagulopathy: A case series. Br J Dermatol 158(6): 1363-1370, 2008. PMID: 18410425. DOI: 10.1111/j.1365-2133.2008.08546.x

12 Emre S and McKenna GJ: Liver tumors in children. Pediatr Transplant 8(6): 632-638, 2004. DOI: $10.1111 / \mathrm{j} .1399-$ 3046.2004.00268.x

13 Moon SB, Kwon HJ, Park KW, Yun WJ and Jung SE: Clinical experience with infantile hepatic hemangioendothelioma. World J Surg 33(3): 597-602, 2009. PMID: 19132441. DOI: 10.1007/ s00268-008-9882-4

14 Ganguly R and Mukherjee A: Infantile hemangioendothelioma: A case report and discussion. Pathol Res Pract 206(1): 53-58, 2010. PMID: 19321270. DOI: 10.1016/j.prp.2009.01.017

15 Sevinir B and Ozkan TB: Infantile hepatic hemangioendothelioma: Clinical presentation and treatment. Turk J Gastroenterol 18(3): 182-187, 2007. PMID: 17891692.

16 Hsi Dickie B, Fishman SJ and Azizkhan RG: Hepatic vascular tumors. Semin Pediatr Surg 23(4): 168-172, 2014. DOI: 10.1053/j.sempedsurg.2014.06.018.

17 Zenge JP, Fenton L, Lovell MA and Grover TR: Case report: Infantile hemangioendothelioma. Curr Opin Pediatr 14(1): 99102, 2002. PMID: 11880743.

18 Mortele KJ, Vanzieleghem B, Mortele B, Benoit Y and Ros PR: Solitary hepatic infantile hemangioendothelioma: Dynamic gadolinium-enhanced mr imaging findings. Eur Radiol 12(4): 862-865, 2002. DOI: 10.1007/s003300101004

19 Mulliken JB and Glowacki J: Hemangiomas and vascular malformations in infants and children: A classification based on endothelial characteristics. Plast Reconstr Surg 69(3): 412-422, 1982. PMID: 7063565

20 Liang MG and Frieden IJ: Infantile and congenital hemangiomas. Semin Pediatr Surg 23(4): 162-167, 2014. PMID: 25241092. DOI: $10.1053 /$ j.sempedsurg .2014.06.017
21 Takahashi K, Mulliken JB, Kozakewich HP, Rogers RA, Folkman J and Ezekowitz RA: Cellular markers that distinguish the phases of hemangioma during infancy and childhood. J Clin Invest 93(6): 2357-2364, 1994. PMID: 294441. DOI: 10.1172/ JCI117241

22 Shayan YR, Prendiville JS and Goldman RD: Use of propranolol in treating hemangiomas. Can Fam Physician 57(3): 302-303, 2011. PMID: 21402965.

23 Tan ST, Itinteang T and Leadbitter P: Low-dose propranolol for infantile haemangioma. J Plast Reconstr Aesthet Surg 64(3): 292-299, 2011. PMID: 20615772. DOI: 10.1016/j.bjps.2010. 06.010

24 Leaute-Labreze C, Hoeger P, Mazereeuw-Hautier J, Guibaud L, Baselga E, Posiunas G, Phillips RJ, Caceres H, Lopez Gutierrez JC, Ballona R, Friedlander SF, Powell J, Perek D, Metz B, Barbarot S, Maruani A, Szalai ZZ, Krol A, Boccara O, FoelsterHolst R, Febrer Bosch MI, Su J, Buckova H, Torrelo A, Cambazard F, Grantzow R, Wargon O, Wyrzykowski D, Roessler J, Bernabeu-Wittel J, Valencia AM, Przewratil P, Glick S, Pope E, Birchall N, Benjamin L, Mancini AJ, Vabres P, Souteyrand P, Frieden IJ, Berul CI, Mehta CR, Prey S, Boralevi F, Morgan CC, Heritier S, Delarue A and Voisard JJ: A randomized, controlled trial of oral propranolol in infantile hemangioma. N Engl J Med 372(8): 735-746, 2015. PMID: 25693013. DOI: 10.1056/NEJMoa1404710

25 Tan ST, Itinteang T and Leadbitter P: Low-dose propranolol for multiple hepatic and cutaneous hemangiomas with deranged liver function. Pediatrics 127(3): e772-776, 2011. PMID: 21357335. DOI: $10.1542 /$ peds.2010-1703

26 Leaute-Labreze C, Dumas de la Roque E, Hubiche T, Boralevi F, Thambo JB and Taieb A: Propranolol for severe hemangiomas of infancy. N Engl J Med 358(24): 2649-2651, 2008. PMID: 18550886. DOI: 10.1056/NEJMc0708819

27 Yang K, Peng S, Chen L, Chen S and Ji Y: Efficacy of propranolol treatment in infantile hepatic haemangioma. $\mathrm{J}$ Paediatr Child Health, 2019. DOI: 10.1111/jpc.14375

28 Foley LS and Kulungowski AM: Vascular anomalies in pediatrics. Adv Pediatr 62(1): 227-255, 2015. PMID: 26205116. DOI: 10.1016/j.yapd.2015.04.009

$29 \mathrm{Yu}$ Y, Flint AF, Mulliken JB, Wu JK and Bischoff J: Endothelial progenitor cells in infantile hemangioma. Blood 103(4): 13731375, 2004. DOI: 10.1182/blood-2003-08-2859

30 Dehner LP: The challenges of vasoformative tumors of the liver in children. Pediatr Dev Pathol 7(5): 527-532, 2004. PMID. 15568213.

31 Selby DM, Stocker JT, Waclawiw MA, Hitchcock CL and Ishak $\mathrm{KG}$ : Infantile hemangioendothelioma of the liver. Hepatology 20(1 Pt 1): 39-45, 1994. PMID: 8020903.

32 Becker JM and Heitler MS: Hepatic hemangioendotheliomas in infancy. Surg Gynecol Obstet 168(2): 189-200, 1989. PMID: 2643192.

33 Mac-Moune Lai F, To KF, Choi PC, Leung PC, Kumta SM, Yuen PP, Lam WY, Cheung AN and Allen PW: Kaposiform hemangioendothelioma: Five patients with cutaneous lesion and long follow-up. Mod Pathol 14(11): 1087-1092, 2001. DOI: 10.1038/modpathol.3880441

34 Garzon MC, Enjolras O and Frieden IJ: Vascular tumors and vascular malformations: Evidence for an association. J Am Acad Dermatol 42(2 Pt 1): 275-279, 2000. DOI: 10.1016/S01909622(00)90138-5 
35 Beaubien ER, Ball NJ and Storwick GS: Kaposiform hemangioendothelioma: A locally aggressive vascular tumor. J Am Acad Dermatol 38(5 Pt 2): 799-802, 1998. PMID: 9591789.

36 Liu XH, Li JY, Qu XH, Yan WL, Zhang L, Yang C and Zheng JW: Treatment of kaposiform hemangioendothelioma and tufted angioma. Int $\mathrm{J}$ Cancer 139(7): 1658-1666, 2016. PMID: 27252149. DOI: $10.1002 /$ ijc. 30216

37 Enjolras O, Wassef M, Mazoyer E, Frieden IJ, Rieu PN, Drouet L, Taieb A, Stalder JF and Escande JP: Infants with kasabachmerritt syndrome do not have "true" hemangiomas. J Pediatr 130(4): 631-640, 1997. PMID: 9108863.

38 Zukerberg LR, Nickoloff BJ and Weiss SW: Kaposiform hemangioendothelioma of infancy and childhood. An aggressive neoplasm associated with kasabach-merritt syndrome and lymphangiomatosis. Am J Surg Pathol 17(4): 321-328, 1993. PMID: 8494101.

39 Ekfors TO, Kujari H and Herva R: Kaposi-like infantile hemangioendothelioma. Am J Surg Pathol 17(3): 314-317, 1993. PMID: 8434712.

40 Enjolras O, Soupre V and Picard A: Uncommon benign infantile vascular tumors. Adv Dermatol 24: 105-124, 2008. PMID: 19263597.

41 McMahon AP, Ingham PW and Tabin CJ: Developmental roles and clinical significance of hedgehog signaling. Curr Top Dev Biol 53: 1-114, 2003. PMID: 12509125.

42 Teglund S and Toftgard R: Hedgehog beyond medulloblastoma and basal cell carcinoma. Biochim Biophys Acta 1805(2): 181208, 2010. DOI: 10.1016/j.bbcan.2010.01.003

43 Wendling-Keim DS, Wanie L, von Schweinitz D, Grantzow R and Kappler R: Transcriptional activation of hedgehog pathway components in aggressive haemangioma. Exp Dermatol 26(10): 934-939, 2017. PMID: 28370639. DOI: 10.1111/exd.13346

44 Pfaffl MW: A new mathematical model for relative quantification in real-time RT-PCR. Nucleic Acids Res 29(9): e45, 2001. PMID: 11328886.

45 Dell'Era P, Coco L, Ronca R, Sennino B and Presta M: Gene expression profile in fibroblast growth factor 2-transformed endothelial cells. Oncogene 21(15): 2433-2440, 2002. DOI: 10.1038/sj.onc. 1205301

46 North PE, Waner M, Mizeracki A and Mihm MC Jr.: Glut1: A newly discovered immunohistochemical marker for juvenile hemangiomas. Hum Pathol 31(1): 11-22, 2000. PMID: 10665907.

47 Gnarra M, Behr G, Kitajewski A, Wu JK, Anupindi SA, Shawber CJ, Zavras N, Schizas D, Salakos C and Economopoulos KP: History of the infantile hepatic hemangioma: From imaging to generating a differential diagnosis. World J Clin Pediatr 5(3): 273-280, 2016. PMID: 27610342. DOI: 10.5409/wjcp.v5.i3.273

48 Burrows PE, Dubois $\mathrm{J}$ and Kassarjian A: Pediatric hepatic vascular anomalies. Pediatr Radiol 31(8): 533-545, 2001. DOI: 10.1007/PL00006641
49 Perez J, Pardo J and Gomez C: Vincristine--an effective treatment of corticoid-resistant life-threatening infantile hemangiomas. Acta Oncol 41(2): 197-199, 2002. PMID: 12102167.

50 Bielenberg DR, Bucana CD, Sanchez R, Mulliken JB, Folkman $\mathrm{J}$ and Fidler IJ: Progressive growth of infantile cutaneous hemangiomas is directly correlated with hyperplasia and angiogenesis of adjacent epidermis and inversely correlated with expression of the endogenous angiogenesis inhibitor, ifn-beta. Int J Oncol 14(3): 401-408, 1999. PMID: 10024670.

51 Chang J, Most D, Bresnick S, Mehrara B, Steinbrech DS, Reinisch J, Longaker MT and Turk AE: Proliferative hemangiomas: Analysis of cytokine gene expression and angiogenesis. Plast Reconstr Surg 103(1): 1-9; discussion 10, 1999. PMID: 9915157.

52 Cohen MM Jr.: Hemangiomas: Their uses and abuses. Am J Med Genet A 143A(3): 235-240, 2007. DOI: 10.1002/ajmg.a.31571

53 Tille JC and Pepper MS: Hereditary vascular anomalies: New insights into their pathogenesis. Arterioscler Thromb Vasc Biol 24(9): 1578-1590, 2004. DOI: 10.1161/01.ATV.0000137390. 56554.df

54 Gupta A and Kozakewich H: Histopathology of vascular anomalies. Clin Plast Surg 38(1): 31-44, 2011. PMID: 21095470. DOI: $10.1016 /$ j.cps.2010.08.007

55 Wendling-Keim DS, Wanie L, von Schweinitz D, Grantzow R and Kappler R: Transcriptional activation of hedgehog pathway components in aggressive haemangioma. Exp Dermatol 26(10): 934-939, 2017. DOI: 10.1111/exd.13346

56 Mavromatakis YE, Lin W, Metzakopian E, Ferri AL, Yan CH, Sasaki H, Whisett J and Ang SL: Foxa1 and foxa2 positively and negatively regulate shh signalling to specify ventral midbrain progenitor identity. Mech Dev 128(1-2): 90-103, 2011. PMID: 21093585. DOI: $10.1016 /$ j.mod.2010.11.002

57 Ferri AL, Lin W, Mavromatakis YE, Wang JC, Sasaki H, Whitsett JA and Ang SL: Foxa1 and foxa2 regulate multiple phases of midbrain dopaminergic neuron development in a dosage-dependent manner. Development 134(15): 2761-2769, 2007. DOI: $10.1242 /$ dev.000141

58 Sasaki H, Hui C, Nakafuku M and Kondoh H: A binding site for gli proteins is essential for HNF-3beta floor plate enhancer activity in transgenics and can respond to $\mathrm{SHH}$ in vitro. Development 124(7): 1313-1322, 1997. PMID: 9118802.

59 Barakat MT, Humke EW and Scott MP: Learning from jekyll to control hyde: Hedgehog signaling in development and cancer. Trends Mol Med 16(8): 337-348, 2010. PMID: 20696410. DOI: 10.1016/j.molmed.2010.05.003 